\title{
CONCEPTUALIZING AUTHORITY OF THE LEGALIZATION OF INDONESIAN WOMEN'S RIGHTS IN ISLAMIC FAMILY LAW
}

\author{
Abu Rokhmad \\ UIN Walisongo, Semarang - Indonesia | aburokhmad@walisongo.ac.id \\ Sulistiyono Susilo \\ Diponegoro University, Semarang - Indonesia | sulistiyonosusilo@gmail.com
}

\begin{abstract}
Various studies on Islamic family law (IFL) in Indonesia demonstrate an enduring paradigm of patriarchal culture both in ideas and practical applications. This is a logical consequence of the attempts to enact the traditional Islamic doctrines in modern law. The domination of this culture in the IFL, that has resulted in the discrimination against women in Indonesia, has reached the alarming level calling for revision. The reform attempts also are needed in other derivative legal products, such as local sharia regulation. All these efforts are needed in order to ensure justice and equal rights of children and women. This paper attempts to conceptualize a construction of patriarchal authority in legalizing the rights, role, and status of gender in Indonesia. The finding reveals that reconstruction of authority in the modern legislation of Islamic Family Law should be started with ensuring the equal rights of women both in the legal and judicial aspects. This requires involving women in an appropriate proportion within the making of public policy, family law legislation. Another needed strategy is advocacy of women's rights in order to avoid legal gender bias due to the political and legislative authorities dominated by male group.
\end{abstract}

Keywords: Legal authority, Islamic family law, women rights.

\section{Introduction}

Indonesia, as the largest democratic Muslim country in the world, has attempted to promote a restorative face in fulfilling the gender rights. Continuous efforts in eliminating gender discrimination have 
been made by the country and one of the efforts is through the capacity building of the legislation and some legal related matters to improve the equal rights and status of women. To give illustration, several articles in the Marriage Law No. 1 year 1974 and Compilation of Islamic Law year 1991 have provided legal protection to women and children. Additionally, a number of laws and covenants have been approved and ratified for the same purpose, such as the regulation on the elimination of domestic violence (2004), on the victims' protection (2006), and on the anti-trafficking (2007). Furthermore, reform of the judicial system has also been introduced by religious courts ${ }^{1}$.

However, massive discrimination against Indonesian women is still a prevalence, not only a matter of doctrine, but rather the existence and dominance of religious and political authority insensitive to gender issue. Legislation of family law, traditional compilation of Islamic law and trial practices where judges prioritize the classical religious argument in determining the verdict, have restricted women's rights in both the domestic and public sphere. All these conditions have led to a call for revision and improvement of the legal products in order to ensure the justice and equal rights of children and women.

Study of gender issues in Indonesia, and particularly its relationship with Islam, remains an ever-appealing topic to be discussed. One of the most interesting facts is the absence of political will to promote reform and renew of the most fundamental family law, the Marriage Act of 1974. Therefore, in order to promote the reconceptualization, this paper firstly will describe the rights and legal status of women in Indonesia in the case of divorce, wife living after the divorce, and inheritance. This paper seeks to re-conceptualize a construction of patriarchal authority in legalizing the rights, role, and status of gender in Indonesia by reconsidering the gender authority conception of the sacred texts-the Quran, sunnah, and Islamic jurisprudence literatures-and modern legal system.

\section{Rights and Status of Indonesian Women}

In the case of elimination of gender bias, Indonesia's achievements are reflected in the Gender-related Development Index (GDI), right

\footnotetext{
${ }^{1}$ Elli N. Hayati, Maria Emmelin, and Malin Eriksson, "We no Longer Live in the Old Days: a Qualitative Study on the Role of Masculinity and Religion for Men's Views on Violence within Marriage in Rural Java, Indonesia," BMC women's health, 14 (1) (2014), p. 58.
} 
behind the neighboring countries (World Bank, 2014; UNDP, 2014). In 2013, Indonesia's GDI is at the $98^{\text {th }}$ out of 186 countries. This position is slightly different from 2002 , taking the $91^{\text {st }}$ position out of 144 countries. Although Indonesian women today are more fortunate as they are treated more fairly than before, in many cases, expectations and intentions of better treatment for them have not been executed completely in accordance with their interests. Various studies ${ }^{2}$ on Islamic family law of Indonesia demonstrate an enduring paradigm of the traditional Islamic legal doctrines and patriarchal culture both in the ideas and in the practical applications. Moreover, the data from World Bank (2014) and United Nations Development Program (2014) reveal that social status of Indonesian women is below their counterpart of men, indicate by literacy rates ( $86 \%$, compared to $94 \%$ for men), shorter time of schooling for women (6.9 years, compared to 8.1 years for men), low rate of women participation in employment (51\%, compared to $84 \%$ for men), low rate of GNI per capita for women (5,873 US \$, compared to 12,030 US $\$$ for men), lower portion of income for women (38\%, compared to $62 \%$ for men), and a small portion of parliamentary seats $(18.6 \%$, compared to $81.4 \%$ for men). Those facts have lowered the attainment quality of a higher life expectancy for women (72.9 years, compared to 68.8 years for men).

Furthermore, there is a deep concern from the Indonesian feminists about some regulations enacted at the national and regional level that seem to have become systematic efforts to discriminate against women. Some ${ }^{3}$ argue that the formalization of Islamic norms into modern laws has associated Islam with rigidity in regard to the tendency of the state to restrict the chosen Islamic values for inclusion in the modern law. A study by Komnas Perempuan (the National Commission for Women) (2012) reveals that the formalization of the Islamic laws in many regions in Indonesia has discriminated the rights and position of women in the public sphere. Until 2012, there were

\footnotetext{
2 A. Feillard, "Indonesia's Emerging Muslim Feminism: Women Leaders on equality, Inheritance and other Gender Issues," Studia Islamika, 4(1) (1997); S. Van Wichelen, Religion, Politics and Gender in Indonesia: Disputing the Muslim Body (UK: Routledge, 2010).

3 Nahda Shehada, "Flexibility versus rigidity in the practice of Islamic family law," PoLAR: Political and Legal Anthropology Review 32:1 (2009), pp. 30; Amira Mashhour, "Islamic Law and Gender Equality: Could there be a Common Ground?: A Study of Divorce and Polygamy in Sharia Law and Contemporary Legislation in Tunisia and Egypt," Human Rights Quarterly, 27:2 (2005), p. 562.
} 
only about 78 local regulations that supported women's rights. In contrast, there are about 282 local regulations imposed by 69 districts/ municipalities in 21 provinces that have violated women's rights. Not only that, those regulations also can be criticized for being not in line with the national official philosophical foundations, Pancasila and the 1945 Constitution. Issues such as freedom of expression, represented by restrictions on the dress code for women, the reduced protection and legal guarantee for women in criminalization through regulation (qanun) on prostitution and seclusion, and the elimination of the migrant workers' right protection indeed are in compatible with the principles within Pancasila and 1945 Constitution. What adds to the concern of the feminists is the fact that this phenomenon of local regulations have increased significantly from 64 regulations in 2006 to 154 regulations in 2010. In 2013, this figure again increases up to 342 regulations.

In the context of domestic aspect, some provisions in the Islamic Family Law also reflect a conservative approach on Islamic jurisprudence in the Islamic legal system in Indonesia. For example, the Islamic family law in Indonesia (Act No. 1 of 1974 on Marriage and the Compilation of Islamic Law in 1991) has dictated social norms that tend to be restrictive in the roles division between men and women. Article VI (paragraph 31 (3) and paragraph 34 (1) and (2) of Law No. 1. 1974) and Article XII (paragraph 80 and 83 of the Compilation of Islamic Law in 1991) state that males are the head of the family and females are the head of household.

\section{Islamic Family Law (IFL) in Indonesia}

Indonesian IFL system basically aims to ensure the equal rights of women. For instance, in the aspect of divorce, Indonesia has limited the practice of unilateral divorce of husband by ruling that a divorce between the husband and wife must be legitimized by the court. Indonesian Islamic Family Law, commonly known as the 1974's Marriage Acts and the 1991's Compilation of Islamic Law, includes detailed rules regarding divorce and its specific basics. Both the husband and wife have the same right to divorce their partner even though there will be different ways and terms. Admittedly, this actually shows a good reform in the case of divorce. Moreover, as stated before, there is also a right for women to pursue for divorce by Khulu' mechanism that is the wife's petition, which is secured through a 
divorce lawsuit with financial compensation from the husband, known as khulu' (a divorce that is decided on the will of a wife) ${ }^{4}$.

Family Law introduces two methods of divorce that can be chosen by a wife, as stipulated in Article 148 of the Compilation of Islamic Laws. After the two parties agree the financial compensation to be paid (iwadl), the Religious Court issues a decision that allows the husband to execute the divorce through thalaq (Article 4). In this case, there is no appeal. However, if no agreement was reached with regard to the amount of compensation, the Religious Courts will examine and consider the case as a regular case (Article 6).

In other words, divorce is not processed as khulü, or not all petitions (divorce lawsuit) can be implemented through khulu'. This Article of the Compilation of Islamic Laws, formulated based on the classical Islamic legal doctrine, is one of the key reforms in which the wife is given her right to file divorce without having to pay financial compensation. On the other hand, her rights on basic necessities are guaranteed by her ex-husband when the divorce process is not by means of khulü. ${ }^{5}$

The Compilation of Islamic Laws also contains substantial provisions guaranteeing the women's rights in the post-divorce although the classical rules do not discuss them in details. Basically, the rights are related to the duty of the mother as the primary custodian for the children who are under 12 years old (Article 105). The rights of the cost of living for children have been regulated by Article 156 (d) of the Compilation of Islamic Laws, where the ex-husband or the father is obliged to provide financial support for the children according to his capacity. This support continues until the children reach the age of 21 years when they are mature and able to support themselves. Even though the obligations of the father actually is also regulated in the classical figh, KHI makes it clear and legal within the scope of Indonesian authority. Moreover, it also adds explanation on the age of the children that has the right for the father support.

\footnotetext{
${ }^{4}$ Ghita Arina Farihin, M. Zainuddin, and M. Rozi Iskandar, "Analysis of The Causing Factors of Divorce Court in The Contested Religion Class 1A Bandung (Case Study from The Year 2013 to 2015)," (2017). Available online at http://202.150.151.113/handle/123456789/9288

${ }^{5}$ Euis Nurlaelawati, "Sharia-Based Laws: The Legal Position of Women and Children in Banten and West Java" Regime Change, Democracy and Islam: The Case Of Indonesia (Final Report Islam Research Programme, Jakarta (2013), pp. 11-81.
} 
However, the religious and political authorities still have to complete the assurance of the legal rights of women in custody of children and necessities after divorce. This is due to the fact that in many cases, legal guarantees of the women's rights have not been granted adequately. In the case of necessities of life after divorce, for example, judicial instruments are needed to strengthen and execute the judge's rulings.

Another issue of gender bias is in the case of inheritance rights. In this regards, the patriarchal authority still seem to have strong intention to maintain the classical formula of inheritance rights, both in the legal and judicial aspects. Unfortunately, the major breakthrough and reform made in the regulation regarding polygamy and divorce through State intervention are not apparent within the aspect of inheritance. The evidence is that the regulation of inheritance is still in favor with the patriarchal view ${ }^{6}$. Another issue is related to the fulfillment of the wife's rights after divorce. Here, the KHI stated clearly that the husband is obliged to provide several things among them are mut'ah (money or a living), shelter, and kiswah (clothes) to the ex-wife. Mut'ah is a once-lifetime gift while nafaqah and kiswah and shelter are obliged during iddah only (the waiting period after wife is divorced) (Article 149). Even though the regulations seem quite protective towards women, the reality speaks different. The problem lays on the fact that the religious court does not have sufficient instruments to strengthen the execution of their decision outside the court. The court seems helpless and is not able to do anything when the ex-husband tries to neglect the decision ${ }^{7}$. Stijn van Huis' research on the Indonesian Religious Courts indicates some problems for women in the form of the weakness of the supporting elements of judicial decision and procedural mechanisms for the fulfillment of the rights of the ex-wives and children to force the ex-husband to fulfill his duty or obligation (Van Huis, 2013: 82). In addition to that problem, there is also a discriminatory clause, which is retained, and that is the imbalance of

\footnotetext{
${ }^{6}$ Javaid Rehman, "The Sharia, Islamic Family Laws and International Human Rights Law: Examining the Theory and Practice of Polygamy and Talaq," in International Journal of Law, Policy and the Family 21:1 (2007), pp. 108; Mounira M Charrad, "Tunisia at the Forefront of the Arab World: Two Waves of Gender Legislation," Wash \& Lee L. Rev, 64 (2007): p. 1513. Mashhour, "Islamic Law and Gender Equality, p. 562.

7 Kees Van Dijk, "Sharia-Based Laws and Regulations," Regime Change, Democracy and Islam: The Case of Indonesia (Final Report Islam Research Programme, Jakarta, 2013), p. 7.
} 
obligation on who can be judged as conducting nushü. Article 151 stated that the husband has obligation to provide his wife as far as she is not in the nushü condition, or behave disobediently ${ }^{8}$.

Here, the obligation to behave obediently is imposed only to the wife as there is no obligation for the husband to behave in a similar way. ${ }^{9}$ As a result, the wife is in a weak position when the husband ignores the court rulings to fulfill the rights of the ex-wife accused of doing nushī (wife violation through disobedience) ${ }^{10}$. Admittedly, there is a room allows for women to pursue demand to the court to force the husband to fulfill the obligation. Unfortunately, this is not as explicit and as effective as the regulation on the wife's nushiz:

If we look closely and critically on to this, the flaw of the legal and judicial rights of the wife accused of doing nushurz stemed from the gender bias assumption and that is the view on the position and roles of husband and wife within the household. KHI stated clearly that the husband serves as the head of the family while the wife is the housewife who passively receive the revenue from her husband ${ }^{11}$. As it is not discriminatory enough, we also see that the meaning of marriage, by ruling that the nafaqab is associated with the obedience, has been distorted to a trade transaction rather than the contractual relationship promoting equality between the sexes. The consequence here is the wife becoming subordinate to the husband ${ }^{12}$. The construction of gender roles (Article 33 and 34 of the Marriage Law) produces a logical and legal framework which is retained in the family law and requires compliance of the wife to the husband with compensation of rights and obligations between the two parties ${ }^{13}$.

${ }^{8}$ Lily Zakiyah Munir, "Islam, Gender, and Formal Shari'a in Indonesia," available at http://www. law. emory. edu/IHR/worddocs/lily2.doc.

9 Zainah Anwar and Rumminger Jana S, "Justice and Equity in Muslim Family Laws: Challenges, Possibilities, and Strategies for Reform," Wash. \& Lee L. Rev. 64 (2007), pp. 1529; Ziba Mir-Hosseini, "Towards Gender Equality: Muslim Family Laws and the Shari'ah," in Zainah Anwar (ed.), Wanted: Equality and Justice in the Muslim Family (Musawah, 2009), p. 23.

10 S Schroter, "Between 'sastra wangi' and 'perda sharia': Debates over gendered citizenship in post-authoritarian Indonesia," RIMA, Review of Indonesian and Malaysian Affairs, 48(1) (2014), p. 67.

11 Mir-Hosseini, "Towards Gender Equality, p. 23

12 Azizah Yahia al-Hibri, "Muslim Women's Rights in the Global Village: Challenges and Opportunities," The Journal of Law and Religion (2000): pp. 37-66.

${ }^{13}$ Mir-Hosseini, “Towards Gender Equality, p. 23 
Another aspect, as mentioned briefly before, is the inheritance rights. The inheritance regulation still reflects the gender bias and patriarchal structure by the religious authorities. Article 176 of Book II of the Compilation of Islamic Laws about inheritance which explicitly refers to the adoption of traditional Islamic doctrines, has given the male's portion two times bigger than the female's portion. For most feminists, such distribution is not fair and, therefore, demand equal rights between women and men in term of inheritance ${ }^{14}$. Moreover, since the State has not imposed the equality of inheritance in the legal and judicial system, it still takes efforts to interpret the tradition of Islamic law so that the law will be in line with the conception of the Indonesian practices ${ }^{15}$.The state seems not having a direction on how promoting new and fairer inheritance division while at the same time also maintaining the classical formulation. The State authority does not have yet sufficient legal and judicial instruments to regulate the division of inheritance in a balanced portion between men and women in accordance with contemporary demands while at the same time retaining the fundamental formulation of classical heritage ${ }^{16}$. This case is different from the divorce problem, in which the state is able to maintain the classical formulation but also promotes reform and that is the shift of the authority to divorce from individuals to the hands of the State in order to ensure the gender equality.

Still related to the inheritance issue, the court in Indonesia also seems not having a superior authority in regards to cases of the inheritance. ${ }^{17}$ In some Muslim countries, there is a freedom to choose the legal system that will be used to resolve inheritance cases in the family and marriage and this is a form of protection given by the

14 Siti Musdah Mulia and Mark E. Cammack, "Toward A Just Marriage Law: Empowering Indonesian Women Through A Counter Legal Draft," Michael R Feener and Mark E. Cammack, Islamic Law in Contemporary Indonesia: Ideas and Institutions. Vol. 5 (Islamic Legal Studies Program, 2007).

15 Mark E Cammack, "Inching Toward Equality: Recent Developments in Indonesian Inheritance law," Indonesian Law and Administration Review 5:1 (1999), p. 50.

${ }^{16}$ Andra Nahal Behrouz, "Transforming Islamic Family Law: State Responsibility and the Role of Internal initiative," Colum. L. Rev. 103 (2003): p. 1136.

17 Andra Nahal Behrouz, "Transforming Islamic Family Law, p. 1136; Daniel S Lev, "Judicial Authority and the Struggle for an Indonesian Rechtsstaat," Law and Society Review (1978), p. 205. 
state $^{18}$. In Indonesia, the state does not give option for Muslims to choose which mechanism in accordance to their will and believe in the dispute over the inheritance resolution through a common judicial body with the orientation of a balanced division formulation. In this case, the state, which is the central authority to solve the disputes of the Islamic law doctrines including the different approaches to understand Islam, is absent in addressing the issue and solving the case $^{19}$. Thus, there are more imperative action to provide more substantive approaches dividing the inheritance in a balanced portion. For example, the State can encourage the males to voluntarily divide the inheritance in a balanced or even greater portion for women in accordance with their needs. Alternatively, anyone who is in serious need of the two parties will get the inheritance in accordance with the agreement reached between the two, passed by the court, and legally guaranteed. This, in our opinion, is the fair conception.

The primary justification on reinterpretation and reform of the inheritance laws is in demands now in order to promote the more compatible inheritance law with the social realities and sensibilities of Indonesian law, as in recognition of joint property in Chapter VII, Article 35-37 of the Marriage Law. Actually, the legalization of the practice of the joint property division, though not found in classical jurisprudence, is the adoption and recognition of the great local wisdom from the tradition and the dynamics of Islamic law in Indonesia. Here, we argue that even if such rules is not found in detail and explicitly in the classical fiqh, they are actually in accordance with the fundamental principles of Islam. The purpose of the doctrinal corpus reinterpretation in terms of inheritance is to achieve a synthesis scheme of inheritance between doctrines of Islam as well as a desire to eliminate the inferior legal status of women in classical Islamic law ${ }^{20}$.

\footnotetext{
18 Jan Michiel Otto, Sharia Incorporated: A Comparative Overview of the Legal Systems of Twelve Muslim Countries in Past and Present (Leiden: Leiden University Press, 2010).

19 Natasha Bakht, "Family Arbitration Using Sharia Law: Examining Ontario's Arbitration Act and Its Impact on Women," Muslim World Journal of Human Rights 1.1 (2004).

20 Michael Barry Hooker, Indonesian Islam: Social Change Through Contemporary Fatäwā. (Hawaii: University of Hawaii Press, 2003).
} 


\section{Orthodox Orientation of Islamic Family Law Legislation}

Reform of family law is a multifaceted issue that reflects social and political debate with two orientations. The first is the traditional group that maintains a literal reading of the doctrinal corpus. The second is the modernist group that promotes reinterpretation of the original sources of Islam, i.e., al-Quran and al-Sunnah ${ }^{21}$. For traditionalconservative group, the modernist's attempt to reinterpret the Islamic law is sometimes seen as an attempt to change the Islamic Law, shari'ah, rather than the Islamic jurisprudence or fiqh. Fiqh, as the Islamic jurists' understanding, which is one of the main sources of the scripturalistic tendency in the family law, is not only a cultural and spiritual heritage of Muslims, but also a force for social change. However, in order to accommodate all the traditionalists and modernists' interests within the family law reform, the specific expertise and high sensitivity is very crucial. One of the most important things needed is the ability to promote the relevance of contemporary ijtibad with the standardization of classical jurisprudence $\operatorname{adoption}^{22}$.

Reconceptualization of authority departs from the interpretation of fiqh which is ideally considered as immutable to change and critics due to the believe that the jurists' understanding is based on the divine perception ${ }^{23}$. Figh should be seen as a dynamic code that can be changed according to the development of civilization. Ideally, when talking about Islamic laws, we should firstly understand the meaning of the term. The term Islamic law is stemed from the word ableam. This term then can be understood as legal matters which refer to a cumulative form of various systems of jurisprudential thinking by various communities and schools of thought concerning with God's purpose and its relationship with public benefit ${ }^{24}$.

21 Mark E Cammack, "Inching Toward Equality, pp. 19; Bruce Maddy-Weitzman, "Women, Islam, and the Moroccan State: The Struggle over the Personal Status Law," The Middle East Journal 59:3 (2005), p. 393.

${ }^{22}$ Fatima Mernissi, Islam and Democracy: Fear of the Modern World (Reading, MA: Addison Wesley, 1992), pp. 18-19.

${ }^{23}$ R Michael Feener and Mark E. Cammack, Islamic Law in Contemporary Indonesia: Ideas and Institutions, Vol. 5 (Islamic Legal Studies Program, 2007).

${ }^{24}$ Khaled Abou el Fadl, "Conceptualizing Shari'a in the Modern State," Vill. L. Rev. 56 (2011), p. 803. 
In this regards, Islamic laws, in the sense of the Islamic jurisprudence, actually were derived from the Islamic jurists who are committed to read the God's words in His sacred text in the golden age of Islam. And, these Islamic laws actually have enormous potential to be reinterpreted through a hermeneutic formulation ${ }^{25}$. In the early Islamic period, the jurists served as the gatekeepers of civil society who maintain their autonomy and independence from the tyranny of the state and political forces vis-à-vis the law of God. The jurisprudence independency of the classical model is difficult to find in the context of modern law legislation that requires political authority as the sole lawmaker. Consequently, the legislation of cultural heritage of the Islamic jurisprudence is associated with the rigidity since the modern state tends to give a perimeter and legitimization only to the selected social norms ${ }^{26}$.

In this case, Islamic Law Compilation (KHI) is considered by Islamic groups as a symbol of the success of the government regime giving the religious court authority to make decisions for cases in the family matters among muslims in Indonesia. The KHI is also seen as the way government facilitate a single and unified legal source and reference for the judges in addressing diverse problems. However, KHI also has significant negative consequences. The existence of a uniform and single reference has actually hinderes or closes doors and opportunities for the creativity of the judges. The existence of KHI also has led stagnancy among the judges as they will feel satisfied and sufficient with the Compilation. Hence, it is very unlikely to see interest among the judges let alone real attempt to seek and explore a variety of answers offered by a variety of Islamic legal literatures. ${ }^{27}$ The provisions in the Compilation better reflect Islamic norms legitimized by the state and limited references in settling disputes between the wealth of literature, methodological variations of the Islamic jurisprudence, and Islamic legal tradition.

${ }^{25}$ Lama Abu-Odeh, "The Politics of (Mis) recognition: Islamic Law Pedagogy in American Academia," The American Journal of Comparative Law (2004), p. 789; Abdullahi Ahmed an-Na'im, "Toward an Islamic Hermeneutics for Human Rights," Human rights and religious values: An uneasy relationship (1995), p. 233; Bernard Freamon, "Some Reflection on Post-Enlightenment Qur'anic Hermeneutics," Michigan State Law Review (2008); Aharon Barak, "Hermeneutics and Constitutional Interpretation," Cardozo L. Rev. 14 (1992), p. 767.

${ }^{26}$ Nahda Shehada, "Flexibility versus rigidity, pp. 28-46.

27 Mulia and Cammack. "Toward A Just Marriage Law, p. 131. 


\section{Legal Justification of Gender-oriented IFL}

The system of modern law legislation makes interpretations and ideas on Islamic legal theories no longer centralized in a single authority, but a blend of various views of specific groups, such as contemporary scholars, Muslim jurists, and activists. One of main challenges faced by the contemporary Muslim societies, and primarily by women, is the challenge to be able to think about the Islamic authority in a new form and model. One issue to be considered is the legitimacy of authority of the women's groups, women religious leaders, and their leadership in the decision-making process of religious, political, and legal products ${ }^{28}$. It is important to note that the religious authority still maintains its important function in the interpretation of classical Islamic jurisprudence eventhough the supremacy of legal authority in modern legislation lies in the national parliament ${ }^{29}$. Therefore, it still very relevant to promote women's right and involvement within the development of Islamic law discourses.

One irony is the fact that even in this modern era, the authority of proposing ideas on Islamic law and the interpretation of divine texts are still being monopolized by male clerics. Here, many argue that it is unavoidable that most legal views are more to the favor of the men. This surely is irrelevant to the modern legislation system in which the state and legislation system requires the approval of people as the owner of sovereignty and the subject of the state and legal control. The necessity of the new models of independent reasoning or ijtihad, according to the spirit of legislation by the legislative council is built on a realistic argument saying that the disparity between the text (nas), and new events is accompanying the dynamics of the history of human civilization. On the other hand, the revelation carrying the divine legal texts has been completed, whereas the problems arising that require new laws are never-ending. In fact, logically, something that seems as if

\footnotetext{
${ }^{28}$ Nimat H Barazangi, "The Absence of Muslim Women in Shaping Islamic Thought: Foundations of Muslims' Peaceful and Just Co-existence," Journal of Law and Religion 24:2 (2008), p. 404; Nimat H Barazangi, "The Absence of Muslim Women in Shaping and Developing Islamic Thought," Theological Review XXX (2009), p. 155.

${ }^{29}$ Haider Ala Hamoudi, "The Death of Islamic law," Georgia Journal of International and Comparative Law 38 (2010), p. 293.
} 
it will change and never end cannot be tied up with constant, unchanged one ${ }^{30}$.

As the implication, the domain of religious authority is mainly in the making of contractual fatwas, rather than realization and formalization of Islamic values within the legal products. The challenge of conventional opposition on such authority is in either the legal authority or ethical agent. A study conducted in Egypt shows that the fatwas of the religious authorities to the ummah are seen more as ethical recommendation than as the legal binding ones ${ }^{31}$. According to the study, fatwa, as one of the practices of the Islamic contractual authority, is a form of authority which is broadly connected with the practice, goodness, and purpose of contemporary Islamic traditions that are formed and then constituted in a modern state through recognition of its accepted status as a reference by the religious courts.

The paradoxical differences between the authority of fatwa and the religious courts have proved that the function of fatwa is more likely as an ethical agency. Although both are derived from the Islamic law, fatwa has a significant authority within the Islamic legal system though it is unofficially established. On the other hand, the religious courts have no meaningful effect like fatwa although they have a legal status ${ }^{32}$.

The domination of the formalistic-particular rather than integrally substantive perspective makes any interpretation outside the religious texts recognized by the conservatives became less effective and unIslamic $^{33}$. In opposing this domination, Muslim feminists have begun exploring a framework covering broader and more comprehensive diversity and pluralistic laws to support the arguments of the reform from diverse perspectives: religion, human rights, constitution, basic rights, and the reality of women's lives ${ }^{34}$.

In such orientation, the classical jurisprudence text is not the only major source. Rather, there will be rooms for eclecticism of various

\footnotetext{
${ }^{30}$ M. Musahadi, "Elemen Liberal dalam Kajian Fikih di Pesantren: Studi atas Ma'had Aly Salafiah Syafi'iyah Sukorejo Situbondo," Asy-Syir'ab: Jurnal Ilmu Syari'ah dan Hukum, 47:1 (2013).

${ }^{31}$ Hussein Ali Agrama, "Ethics, Tradition, Authority: Toward an Anthropology of the Fatwa," American Ethnologist 37:1 (2010), pp. 2-18.

32 Ibid., pp. 2-18.

${ }^{33}$ Shehada, "Flexibility versus rigidity, pp. 28-46.

34 Zainah Anwar (ed.), Wanted: Equality and Justice in the Muslim Family (Musawah, 2009).
} 
multicultural sources of law, including democracy and human rights ${ }^{35}$. Unsurprisingly, in the modern times, the views and ways of the contemporary Muslims in articulating the Islamic law is not only influenced by traditional texts but also affected by by the dominant discourse in the human rights and democracy.

This does not mean that the relationship between the principles of justice, sovereignty or human dignity, or ethical values as the heart of the virtue of humankind and Islamic law has been transplanted in products representing Western values or Western-influenced products. However, there is no doubt that the way the Muslims articulate such an organic relationship among the normative-transcendental values in the form of justice and the virtue of law is expressed in different languages at any given time and place ${ }^{36}$.

Legal diversity encourages more positive and progressive practice of the reform enabling the women's group to be able to show that, with the name of Islam, there are indeed some quite drastic breakthroughs in the family law. The famous examples are found in the ways Tunisia and Turkey forbids polygamy. Another example is the fact that Morocco, through the 2004 Moudawama Reform, resets the minimum age for marriage at 18 for both male and female, reconceptualizes the meaning of ijtibad in modern times.

In this regards, we believe that, if this practice occurs in the name of Islam in some countries, then such practices could and should be replicated and adopted in other countries as well including Indonesia. To be more detail, the reforms of the family law in Muslim countries should be designed in three directions they are equality between partners, equilibrium in the family, and protection for the wife and children's rights ${ }^{37}$.

\footnotetext{
35 Abdul Ghofur and Sulistiyono, "Eklektisisme dalam Taqnin Hukum Keluarga di Dunia Islam," Islamica, Jurnal Studi Keislaman Vol. 8, No. 2 (2014), p. 261; Haider Ala Hamoudi, "Baghdad Booksellers, Basra Carpet Merchants, and the Law of God and Man: Legal Pluralism and the Contemporary Muslim Experience" (2008).

36 el Fadl, "Conceptualizing Shari'a, p. 803; Mohammad Fadel, "The True, the Good and the Reasonable: the Theological and Ethical Roots of Public Reason in Islamic Law," Canadian Journal of Law and Jurisprudence 21:1 (2008), p. 8; R. Randall Kelso, "Modern Moral Reasoning and Emerging Trends in Constitutional and Other Rights Decision-Making Around the World," QLR 29 (2011), p. 433.

37 Fatima Sadiqi and Moha Ennaji, "The Feminization of Public Space: Women's Activism, the Family Law, and Social Change in Morocco," Journal of Middle East Women's Studies 2:2 (2006), p. 86.
} 
Muslim feminists in many Muslim countries use the progress study and law diversity, as well as the practices of Muslims in many countries as tools or arguments to open a discourse as well as to challenge the domination of orthodox authority. Expectedly, those strategies are effective in providing the alternative opinions and hence is able to break the deadlock over the monopoly of authority claiming that it is only religious traditional figures who have the right to interpret the divine texts ${ }^{38}$. For secular states with a democratic constitutional framework, Indonesia included, the concept of monopoly of interpretation over texts, including religious texts, will be quite strange or unideal because national laws and public policies must be contested in a public debate. This is an ideal framework even when the law is made in the name of religion and by the religious authority, KHI is included ${ }^{39}$.

One of the biggest challenge encountered by the feminist Muslims in advocating and justifying the urgency of the reform of the law is the lack of support, or in some cases resistence, from the government or religious authorities ${ }^{40}$. Therefore, the involvement and active participation of traditional scholars in promoting and mainstreaming gender equality is essential to ensure the credibility and validity of the gender activists' authority in reinterpreting fundamental principles of Islam $^{41}$. The most important point of the reform is a concrete manifestation of the implementation of Islamic law in accordance with the context of modern Indonesia, including the judicial system, positive law, and the recognition of the new model of Islamic law legislation draft, in addition to the contemporary models for the implementation of Shari'a ${ }^{42}$.

38 Adrien Katherine Wing and Hisham Kassim, "Future of Palestinian Women's Rights: Lessons from a Half-Century of Tunisian Progress," Wash. \& Lee L. Rev. 64 (2007), p. 1551.

${ }^{39}$ Mark Tessler, "Islam and Democracy in the Middle East: The Impact of Religious Orientations on Attitudes Toward Democracy in Four Arab Countries," Comparative Politics (2002), p. 340.

40 Zainah Anwar and Jana S Rumminger, "Justice and Equity in Muslim Family Laws: Challenges, Possibilities, and Strategies for Reform," Wash. \& Lee L. Rev. 64 (2007), p. 581.

41 Clarissa Adamson, "Gendered Anxieties: Islam, Women's Rights, and Moral Hierarchy in Java," Anthropological Quarterly 80:1 (2007), pp. 22-25.

42 Nurlaelawati, "Sharia-Based Laws, p. 81. 


\section{Conclusion}

Flexibility of the reform on Islamic family law, as one form of figh (jurisprudence), has been demanded by Muslim women. One of the argument is that the modern law is a pure product of the modern legislation and therefore it is different from the sharia. In this regards, they also argue that, in modern legislation, the authority to compose and interpret any text should not be monopolized by some elites, here including the religious figures.

The idea of flexibility actually can be found in scheme of classical fiqh for Muslims. Classical fiqh is a cultural heritage that can be interpreted dynamically in accordance with other factors including times and places. Hence, the people are granted options to be able to adopt and or to adapt to changes and contemporary reality. As a product of legislation, family law is laden with the demands, orientations, interests, and voices of various parties for the fulfillment of gender equality to strengthen legal rights, roles, and social status of women in the domestic and public sphere. In accordance with the assumption that each Muslim generation have the obligation to interpret the primary sources of religion according to the contemporary needs and conditions, the modernists refuse to accept the non-reserve legal classic doctrines. Furthermore, they also advocate the reinterpretation of the God revelation or the divine text to be derived as a set of doctrines that correspond to the modern conditions.

Egalitarianism and emancipation of the religious authority play a very important role in making and assuring the family law that is responsive to the changes troughout times and responsive towards varieties of localities and cultures.

One need very crucial this time is a need to open the space for active participation and involvement of many parties in the process of reevaluation and revision. This is also by accommodating the voices and aspirations from the so-called feminists. Admittedly, there has been a very little space for this. Authority over the legalization of the gender rights given only to male scholars with patriarchal perspective is very contradictory with the fact that the involvement of women to build capability in determining their fate and interests is a must. Therefore, recognition of women's rights is a relevant attempt to accommodate the voices of women and feminism. In the light to conceptualize new authorities of Indonesian IFL accordance with modern reality and demands, it is need eclecticism of various 
multicultural sources of law, including democracy, human rights and legal diversity. Legal diversity encourages more positive and progressive practice of the reform enabling the women's group to be able to show that normative Islamic values can be practiced in the modern days.[]

\section{References}

\section{Books and Articles}

Abu-Odeh, Lama. "The Politics of (Mis) recognition: Islamic Law Pedagogy in American Academia." The American Journal of Comparative Law (2004): pp. 789-824.

Adamson, Clarissa. "Gendered Anxieties: Islam, Women's Rights, and Moral Hierarchy in Java." Anthropological Quarterly 80:1 (2007): pp. 22-25.

Agrama, Hussein Ali. "Ethics, Tradition, Authority: Toward an Anthropology of the Fatwa." American Ethnologist 37:1 (2010): pp. 2-18.

Anwar, Zainah (ed.). Wanted: Equality and Justice in the Muslim Family. Musawah, 2009.

Anwar, Zainah and Jana S Rumminger. "Justice and Equity in Muslim Family Laws: Challenges, Possibilities, and Strategies for Reform." Wash. \& Lee L. Rev. 64 (2007).

Bakht, Natasha. "Family Arbitration Using Sharia Law: Examining Ontario's Arbitration Act and Its Impact on Women." Muslim World Journal of Human Rights 1:1 (2004).

Barak, Aharon. "Hermeneutics and Constitutional Interpretation." Cardozo L. Rev. 14 (1992).

Barazangi, Nimat H. "The Absence of Muslim Women in Shaping Islamic Thought: Foundations of Muslims' Peaceful and Just Co-existence." Journal of Law and Religion 24:2 (2008).

. "The Absence of Muslim Women in Shaping and Developing Islamic Thought." Theological Review XXX 2009 (2009): pp. 155182. 
Behrouz, Andra Nahal. "Transforming Islamic Family Law: State Responsibility and the Role of Internal initiative." Colum. L. Rev. 103 (2003): 1136.

Cammack, Mark E. "Inching Toward Equality: Recent Developments in Indonesian Inheritance law." Indonesian Law and Administration Review 5:1 (1999): pp. 19-50.

Fadel, Mohammad. "The True, the Good and the Reasonable: the Theological and Ethical Roots of Public Reason in Islamic Law." Canadian Journal of Law and Jurisprudence 21:1 (2008).

el Fadl, Khaled Abou. "Conceptualizing Shari'a in the Modern State." Vill. L. Rev. 56 (2011).

Farihin, G. A., M. Zainuddin, and MR. Iskandar. "Analysis of The Causing Factors of Divorce Court in The Contested Religion Class 1A Bandung (Case Study from The Year 2013 to 2015)." Available online at http://202.150.151.113/handle/123456789/9288

Feener, R. Michael, and Mark E. Cammack (eds). Islamic Law in Contemporary Indonesia: Ideas and Institutions. Vol. 5. Islamic Legal Studies Program, 2007.

Feillard, A. "Indonesia's emerging Muslim feminism: women leaders on equality, inheritance and other gender issues." Studia Islamika, 4:1. (1997).

Freamon, Bernard. "Some Reflection on Post-Enlightenment Qur'anic Hermeneutics." Michigan State Law Review (2008).

Ghofur, Abdul and Sulistiyono, "Eklektisisme Dalam Taqnin Hukum Keluarga di Dunia Islam." Islamica: Jurnal Studi Keislaman Volume 8, Nomor 2 (March 2014).

Hayati, E. N., M. Emmelin, and M. Eriksson. "We no longer live in the old days: a qualitative study on the role of masculinity and religion for men's views on violence within marriage in rural Java, Indonesia." BMC women's health, 14:1 (2014).

Hamoudi, Haider Ala. "The Death of Islamic law." Georgia Journal of International and Comparative Law 38 (2010). -. "Baghdad Booksellers, Basra Carpet Merchants, and the Law of God and Man: Legal Pluralism and the Contemporary Muslim Experience." (2008). 
Al-Hibri, Azizah Yahia. "Muslim Women's Rights in the Global Village: Challenges and Opportunities." The Journal of Law and Religion (2000).

Hooker, Michael Barry. Indonesian Islam: Social Change Through Contemporary Fatawwa. Hawaii: University of Hawaii Press, 2003.

Kelso, R. Randall. "Modern Moral Reasoning and Emerging Trends in Constitutional and Other Rights Decision-making around the World." QLR 29 (2011).

Lev, Daniel S. "Judicial Authority and the Struggle for an Indonesian Rechtsstaat." Law and Society Review (1978).

Maddy-Weitzman, Bruce. "Women, Islam, and the Moroccan state: The Struggle Over the Personal Status Law." The Middle East Journal 59:3 (2005).

Mashhour, Amira. "Islamic Law and Gender Equality: Could there be a Common Ground?: A Study of Divorce and Polygamy in Sharia Law and Contemporary Legislation in Tunisia and Egypt." Human Rights Quarterly 27:2 (2005).

Mernissi, Fatima. Islam and Democracy: Fear of the Modern World. Reading, MA: Addison Wesley, 1992.

Mir-Hosseini, Ziba. "Towards Gender Equality: Muslim Family Laws and the Shari'ah." Zainah Anwar (ed.). Wanted: Equality and Justice in the Muslim Family. Musawah, 2009.

Mulia, Siti Musdah and Mark E. Cammack. "Toward a just Marriage Law: Empowering Indonesian Women through a Counter Legal Draft.” R. Michael Feener, and Mark E. Cammack. Islamic Law in Contemporary Indonesia: Ideas and Institutions. Vol. 5. Islamic Legal Studies Program, 2007.

Munir, Lily Zakiyah. "Islam, Gender, and Formal Shari'a in Indonesia." Source: http:// www. law. emory. edu/IHR/worddocs/lily2. doc (accessed 07.05. 2007) (2004).

Musahadi, M. "Elemen Liberal Dalam Kajian Fikih Di Pesantren: Studi Atas Ma'had Aly Salafiah Syafi'iyah Sukorejo Situbondo." AsySyir'ab: Jurnal Ilmu Syari'ab dan Hukum, 47:1 (2013).

an-Na'im, Abdullahi Ahmed. "Toward an Islamic hermeneutics for human rights." Human rights and religious values: An uneasy relationship (1995). 
Nurlaelawati, Euis. "Sharia-Based Laws: The Legal Position Of Women And Children In Banten And West Java" Regime Change, Democracy and Islam: The Case of Indonesia. Final Report Islam Research Programme Jakarta, 2013.

Otto, Jan Michiel. Sharia Incorporated: A Comparative Overview of the Legal Systems of Twelve Muslim Countries in Past and Present. Leiden: Leiden University Press, 2010.

Rehman, Javaid. "The Sharia, Islamic Family Laws and International Human Rights Law: Examining the Theory and Practice of Polygamy and Talaq." International Journal of Law, Policy and the Family 21:1 (2007).

Sadiqi, Fatima and Moha Ennaji. "The Feminization of Public Space: Women's Activism, the Family Law, and Social Change in Morocco." Journal of Middle East Women's Studies 2:2 (2006).

Schroter, S. "Between 'sastra wangi' and 'perda sharia': Debates over gendered citizenship in post-authoritarian Indonesia." RIMA: Review of Indonesian and Malaysian Affairs, 48:1 (2014).

Shehada, Nahda. "Flexibility versus rigidity in the practice of Islamic family law." PoLAR: Political and Legal Anthropology Review 32:1 (2009).

Tessler, Mark. "Islam and Democracy in the Middle East: The Impact of Religious Orientations on Attitudes Toward Democracy in Four Arab Countries." Comparative Politics (2002).

Van Dijk, Kees. "Sharia-Based Laws and Regulations." Regime Change, Democracy and Islam: The Case of Indonesia. Final Report Islam Research Programme Jakarta, 2013. 